\author{
Mirostaw Wasilewski \\ Marzena Ganc \\ Szkoła Gtówna Gospodarstwa Wiejskiego w Warszawie
}

\title{
METHODOLOGY OF COST RECORDING AND ACCOUNTING IN DAIRY COOPERATIVES
}

The purpose of the research is to present the theoretical and practical aspects of determining the unit cost of producing dairy products in what is defined as a "typical" dairy cooperative. The Euclidean and urban distance method was used to determine a typical object with $n=88$ dairy cooperatives the following set of variables was defined, which are common to all cooperatives and reflect the size and specificity of cooperative units on the milk market in Poland. The selected cooperative provides a procedure for calculating the unit costs of dairy products on the basis of a detailed case study. The full cost account used in cooperatives does not provide cost information for management decisions. Indirect cost accounting using contractual factors does not provide reliable cost data. An important issue in determining the coefficients is the adoption of a measure which reflects the actual relationship between cost and cost carrier, a product which, in the case of dairy products, may be difficult. It would be appropriate to attempt to introduce a variable cost account in dairy cooperatives in order to avoid the contractual assignment of indirect costs to products. The main problem highlighted by the authors is the lack of an adequate information system for the cost accounting in dairy cooperatives. The implementation of such solutions would allow managers of a dairy cooperative to make appropriate (short-term) decisions in terms of developing an assortment structure based on data e.g. on profitability at the level of individual products.

Key words: dairy cooperatives, costing calculation, cost accounting.

JEL Codes: M49, Q19, P13.

\section{Introduction}

Cost calculation in dairy cooperatives in Poland has undergone and is still undergoing modifications, dictated by the need for information changes in the period of marketisation in the economy, changes in the scale and scope of activity of economic units, their structures and management methods, the increase in demand for reliable cost information and growing competition on the dairy products market. Reliable cost information is needed under the conditions in which modern businesses operate. Providing this information is the main task of cost accounting, which is one of the most important components of accounting, with the task of grouping costs and establishing a series of relationships between production processes and the amount of costs. Cost calculation should take into account changes occurring both in production technology and in the market environment of the dairy cooperative, as these factors justify the need for cost information (Ganc 2017; Wasilewski, Kowalczyk 2004; Stanisławski 2006).

In economic units operating on the milk market in European countries, the costs incurred in a given period "have always" been recorded in generic accounts and by type of activity (Alnestig, Segersted 1996; Turner, Hilton 1989; Tishlias, Chalos 1988; 
Bruegelmann 1985; Schiff 1987; Doost 2018; Ganc 2017; Dickhaut, Lere 1983; Horngren, Foster, Datar 1997). Indirect costs and other direct costs (excluding costs of milk raw material) are recorded on appropriate accounts of the types of activity, e.g. on the account "auxiliary departments" or "departmental costs" (Jaruga, Nowak, Szychta 1999). The costs of purchase and procurement of raw material are accounted for by nature and the respective amounts are transferred to the "costs of purchase and procurement" account. After the costs are recorded and allocated to the arrangement according to the types of activity, the costs incurred in the earlier periods, but related to the current cost account (period), are settled on the account "settlements of accrued costs" (Bazydło, Sokołowski 1998; Garrison, Noreen 1994; Czubakowska, Gabrusewicz 2006).

A dairy cooperative does not have costing schemes imposed 'from above'. Managers may apply the principles for the calculation of manufactured products according to the assumptions adopted by the management board of a given cooperative or use solutions proposed by various unions and associations of dairy cooperatives, taking into account the standards applicable in accounting (Ganc, Soliwoda 2011). The main rationale for preparing spreadsheets is to determine the unit costs of individual products, needed to make pricing decisions and to analyse the level of costs incurred per unit of product (Ganc 2017). Dairy commodities are mass-produced products from the same raw material but through a variety of production processes, which is why dairy cooperatives use apportionment calculations with factors and addition calculations. In determining the consumption of raw material per unit of production, the apportionment calculation with coefficients is applied, while indirect costs are added to the costs of raw material (milk) using the cost-plus pricing, with the help of appropriately selected apportionment keys (Wasilewski, Chmielewska 2006).

The raw milk is accounted for in the individual products according to the consumption norms for fat and plasma units, sometimes including the consumption norm for protein or casein units - which depends on the decisions of the cooperative's managers. The raw material consumption standard for a product defines the number of fat and plasma units that are used to produce a unit of finished product. The consumption standard is different for each type of product and takes into account the losses incurred in the production process. The cost of a unit of fat is calculated by multiplying the price of a unit of fat by the standard rate of fat consumption per product, while the value of plasma units is obtained by multiplying the price of a unit of plasma by the standard rate of consumption of these units per product ${ }^{1}$. The prices of fat and plasma units are determined according to the following formulae:

$$
\begin{aligned}
& C J T=\frac{S M}{(J T+J B)} \\
& J B=\text { litry } * 3_{2}
\end{aligned}
$$

\footnotetext{
${ }^{1}$ In those cooperatives where the raw material cannot be accounted for directly per product (where the milk comes not only from procurement - from supplier-members of the cooperative, but also from purchase - from other cooperatives), the value of the raw material is accounted for per product on the basis of the weighted average prices of fat units and plasma in purchase and procurement.

$23 \%$ is the average protein content of milk, so the total number of protein units in the production of a product is the number of litres multiplied by 3 . The fat content of milk in cooperatives in Poland can vary, ranging from $3 \%$ to $5 \%$
} 
Where:

$$
C J P=C J T * \frac{J B}{J P}
$$

CJT - price of fat unit, JB - protein units, JT - fat units, JP - plasma units, CJP - price of plasma unit, SM - amount paid for raw milk.

Cost accounting in a dairy cooperative is a specific process, as the main production takes place using only one basic material, which is procured milk (Chmielewska 2006). This material (raw material) must be quickly processed into the final product as it has a short shelf life, which requires appropriate organisation of the production process. The total net dairy raw material cost of a given product is defined as the sum of the value of the fat and plasma units, less the value of the usable waste generated in the manufacture of the product (usable waste is any milk powder sweepings, cheese trimmings, etc.).

Costs by type are allocated to the places where they arise, with particular emphasis on raw material costs, which in dairy cooperatives account for approximately $85 \%$ of all operating costs and purchase and procurement costs. Once the costs by type have been allocated to the places where they arise, the value of work in progress is determined and the cost of dairy products is calculated. After adding the costs of management and sales to the cost of production, the own expense (including the costs of primary and secondary production and the costs of management and sales) is calculated.

\section{Research methodology}

The aim of the research is to present the methodology for determining the unit production cost of dairy products on the example of a typical dairy cooperative, determined using the Euclidean distance and urban distance method [Borkowski, Dudek, Szczesny 2003; Nowak 2001]. The Euclidean distance is defined by the formula:

$$
\begin{aligned}
\mathrm{d}_{\mathrm{ij}}= & \sqrt{\sum_{i=1}^{m}\left(z_{i j}-z_{i j}\right)^{2}} \\
\text { Urban distance is defined by the formula: } & \sqrt{\sum_{j=1}^{m}\left|z_{i j}-z_{i l}\right|}
\end{aligned}
$$

Where:

$\mathrm{d}_{\mathrm{ij}}$ - distance between $\mathrm{i}$ - this and $\mathrm{j}$ - this object,

$\mathrm{z}^{\mathrm{il}}$ - the value of $\mathrm{i}$ - this variable for 1 - this object.

A typical cooperative is characterised by the most close to average magnitudes of the selected variables to be analysed. In order to define a typical object with $n=88$ dairy cooperatives, the following set of variables was defined, which are common for all cooperatives and reflect the size and specificity of cooperative units on the milk market in Poland - $(\mathrm{m}=13): m_{1}$ - value of own fund (PLN), $\mathrm{m}_{2}$ - value of total assets (PLN), $\mathrm{m}_{3}$ value of share fund (PLN), $m_{4^{-}}$size of employment (people), $m_{5}$ - value of processed raw material (PLN), $m_{6}$ - operating costs (PLN), $m_{7}$ - average balance of receivables (PLN), $m_{8}$ - average balance of liabilities (PLN), $m_{9}$ - sales revenue (PLN), $m_{10}$ - profit/loss on 
sales (PLN), $m_{11}$ - net profit/loss (PLN), $m_{12}$ - number of suppliers (people), $m_{13}-$ milk procurement volume (hl).

In a selected typical cooperative, the systematics of calculating unit manufacturing costs of dairy products and the adopted settlement keys for indirect costs, determined on the basis of fat and plasma units, were presented in the form of a case study. The data needed to determine the methodology for determining the cost of dairy production was for 2019 and included both accounting records and non-accounting information (analytical costing, management data). The article attempts to answer the following research questions: 1) How are indirect costs accounted for dairy products and what are the consequences for the level of unit cost? 2) Does the methodology adopted by cooperatives for cost accounting make it possible to take management decisions? 3) What would be the desired direction for changes in the applicable cost accounting to increase information capacity?

\section{Results}

In the calculation of dairy products, account shall be taken of the costs of preparing the production which relate to the product being manufactured for the first time or, where new technology is applied, to the product to which it relates.

The costs of procurement and purchase of raw material are charged directly to the specified product, by means of detailed off-book accounting records. Where it is not possible to allocate purchase and procurement costs directly to a product, coefficients established within the relevant cooperative shall be applied and accounted for on the basis of the net consumption of raw material per product or on the basis of the sum of the imputed units. Purchase and procurement costs are not accounted for on buttermilk and products made from it, and on own whey products, as they do not include imputed units.

Departmental costs are accounted for on a per-product basis through cost-intensity ratios, determined by the cooperative's management and accounting department, multiplied by the volume of production. They are usually determined on the basis of, among other things, labour intensity and product weight. An important issue in determining the coefficients is the adoption of such a measure that will reflect the actual relationship between the cost and the cost carrier - the product, therefore it would be advisable to settle these costs in relation to the net consumption of raw material or the sum of the calculation units.

During the production process of dairy products, products are produced that do not meet the required standards and are not suitable for consumption, but will be sold for other purposes such as feed. The costs of losses due to production shortages are accounted directly to the product in the manufacture of which the shortage was identified. If, on the other hand, by-products are generated in the production of a given product, the production costs of the main product are reduced by the value of the by-products at their selling price ${ }^{3}$.

Management costs, known as overhead, are charged to products, usually taking as a basis the sum of purchase and procurement costs and departmental costs (this may be a different basis depending on the basis established by the cooperative), which are then

\footnotetext{
${ }^{3}$ By-products are valued at their realisable selling prices.
} 
charged to products using a calculated coefficient (overhead divided by the basis for charging these costs).

The basis for accounting for the cost of sales for specific products is off-book records. Selling costs consist of direct costs attributable to the product in question and common costs, which can be calculated as follows:

- the cost of distributing certain dairy products to the retail network in relation to the volume of products sold in a given period,

- other selling costs in relation to all products sold in a given period.

The costs of financial operations directly related to the production of products are accounted for by adopting the basis for calculation, which cooperatives determine on their own (most often it is the technical production cost, management costs and selling costs) (Rogowska 2013).

With all costs accounted for in the spreadsheet, the technical production cost of the product and the total cost of ownership of the product are determined. Manufacturing cost is the sum of net raw material consumption, other direct materials, purchase and procurement costs and departmental costs. Total own expense is determined as the sum of the technical production cost of a product, factory overheads and selling costs.

On the basis of the manufacturing cost and the cost of each product, the unit manufacturing cost and the unit own expense are determined by dividing them by the quantity of the type of product manufactured, respectively. The calculation of dairy products separately includes two more items - the value of production at realisation prices, which includes the production of the product concerned multiplied by the average selling price, and the difference between the value of production at realisation price and the total cost of ownership.

In dairy cooperatives, indirect costs constitute a small part of total production costs (about 10\%), but their allocation to individual products poses many problems (Reinstein, Bayou 1997; Black, Gray 1995). The costs of purchase and procurement of raw material in cooperatives in Poland are settled directly on a specific product, by means of a coefficient established within a given cooperative and they are settled in relation to the net consumption of raw material for a given product or in relation to the sum of calculation units (Wasilewski, Chmielewska 2006).

Dairy products are mass produced using the same raw material but through different production processes. The use of the same raw material makes it possible to calculate the cost of its consumption using a job-order cost accounting with calculation factors, while the use of different processes results in the need to account for indirect costs using joborder cost accounting keys. The dairy calculation methods combine two types of calculation - job-order cost accounting with factors and cost-plus pricing.

Table 1 provides a summary of the raw material income in fat and plasma units.

The cooperative under study procured dairy raw material from farmers (cooperative owners) on an annual basis, in terms of fat and plasma units 15 million and about 4 million calculation units respectively. Raw material from purchases from other cooperatives amounted to about 4 million units of fat and about 1.4 million units of plasma. Total raw milk income, after taking into account reprocessing, shortages, surpluses and transfers between plants, was approximately 19.7 million in fat units, approximately 5.5 million in plasma units. 
Table 1. Overview of raw dairy products

\begin{tabular}{|c|c|r|r|r|r|}
\hline \multirow{2}{*}{ No. } & Content & \multicolumn{2}{|c|}{ Fat } & \multicolumn{2}{c|}{ Plasma } \\
\cline { 3 - 6 } & Puantity & $\begin{array}{c}\text { Value } \\
\text { (PLN) }\end{array}$ & Quantity & $\begin{array}{c}\text { Value } \\
(\text { PLN) }\end{array}$ \\
\hline 1. & Procurement & 15927383 & 3330202 & 4062526 & 2648165 \\
\hline 2. & Purchase & 4030969 & 1123696 & 1447245 & 1293234 \\
\hline 3. & Reprocessing & 17981 & 6128 & 4756 & 5046 \\
\hline 4. & $\begin{array}{c}\text { Differences from transfers } \\
\text { between branches (plants) } \\
\text { shortages }\end{array}$ & 6668 & 1398 & 924 & 602 \\
\hline 5. & Shortages & 526716 & 115908 & 71227 & 50527 \\
\hline 6. & Surpluses & 286804 & 61445 & 61170 & 43690 \\
\hline & Total (1+2+3-4-5+6) & 19729733 & 4404165 & 5503546 & 3938961 \\
\hline
\end{tabular}

Source: authors' own elaboration.

Table 2 shows the cost calculations per unit of fat and plasma. When calculating the costs per unit of fat and plasma, account is taken of work in progress at the beginning of the period, the already calculated raw material receipts converted into fat and plasma and work in progress at the end of the year (also in units of fat and plasma). The cost per fat unit was calculated as the quotient of total fat units and total raw material revenue in fat units and amounted to PLN 0.22 per unit. The plasma cost, which was PLN 0.69 per unit, was calculated as the total plasma units divided by the total raw material revenue in those units.

Table 2. Methodology for the calculation of fat and plasma unit costs

\begin{tabular}{|c|c|c|c|c|}
\hline \multirow[t]{2}{*}{ Content } & \multicolumn{2}{|c|}{ Number of units } & \multicolumn{2}{|c|}{$\begin{array}{l}\text { Value of units } \\
\text { (PLN) }\end{array}$} \\
\hline & Fat & Plasma & Fat & Plasma \\
\hline $\begin{array}{l}\text { 1. Work in progress at } \\
\text { the beginning of the } \\
\text { period }\end{array}$ & 474463 & 90019 & & \\
\hline 2. Raw material income & 19729733 & 5503546 & 4404165 & 3938961 \\
\hline $\begin{array}{l}\text { 3. Production at the end } \\
\text { of the period }\end{array}$ & 563190 & 66696 & & \\
\hline $\begin{array}{l}\text { 4. Total raw material } \\
(1+2-3)\end{array}$ & 19641006 & 5526869 & 4404165 & 3938961 \\
\hline $\begin{array}{l}4 \text { a) including from } \\
\text { purchase: }\end{array}$ & 48904 & 420410 & 9394 & 397195 \\
\hline $\begin{array}{l}4 \text { b) from procurement } \\
(4-4 a)\end{array}$ & 19592102 & 5106459 & 4394771 & 3541766 \\
\hline $\begin{array}{l}\text { 5. Cost per unit at } \\
\text { average unit cost }\end{array}$ & 1 & 1 & $\begin{array}{r}4394771 / 19592102 \\
= \\
0,2243134\end{array}$ & $\begin{array}{r}3541766 / 5106459 \\
= \\
0,6935855\end{array}$ \\
\hline
\end{tabular}

Source: authors' own elaboration.

The raw milk is accounted for in the individual products according to the consumption norms for fat and plasma units, sometimes including the consumption norm for protein. The raw material consumption standard for a product defines the number of fat and plasma units that are used to produce a unit of finished product. The consumption standard is different for each type of product (e.g. for milk with a fat content of $2 \%$ it is 2.01 fat units and 0.98 plasma units) and takes into account the losses incurred in the 
production process. The value of raw milk for individual products is recorded in units of fat and plasma.

Table 3 shows the total consumption of raw material according to the applicable standards for all products manufactured in the cooperative under study. A total of approximately 19.6 million fat units and 5.5 million plasma units were used. The highest consumption of fat units occurred for table butter, extra butter and milk powder. The highest consumption of plasma units (by standards) was recorded for milk powder.

The value of direct materials is charged directly to the product concerned. In the example in question, other direct materials in the amount of PLN 141,688 were used to manufacture the products (the data were obtained directly from the entity's accounting records). Each cooperative has a list of other direct materials, related to the specific product (e.g. other materials for butter are: butter bag, cooking salt, pure cultures for sourdough, etc.). The costs of direct materials are determined at their purchase price. Detailed off-book records shall be kept in respect of them for individual products. The type and value of the particular material needed for the product shall be specified. Those materials which are incorporated in several products are accounted for in proportion to their weight or to the consumption standards set by cooperatives.

Table 3. Raw material consumption by product manufactured in the surveyed cooperative

\begin{tabular}{|c|c|r|r|r|}
\hline \multirow{2}{*}{ No. } & Content & Quantity $(1, \mathrm{~kg})$ & \multicolumn{2}{|c|}{ Consumption according to standards } \\
\cline { 4 - 5 } & & & Fat units & \multicolumn{1}{|c|}{ Plasma units } \\
\hline 1 & Milk powder & 428500 & 3480993 & 4683336 \\
\hline 2 & Packaged table butter & 124455 & 9421282 & 43560 \\
\hline 3 & Extra butter & 59828 & 5022560 & 17948 \\
\hline 4 & Buttermilk feed & 204620 & 81848 & 204824 \\
\hline 5 & Drinking milk $\%$ bottle & 105552 & 213217 & 104496 \\
\hline 6 & Drinking milk $\%$ in bulk & 55943 & $\mathbf{1 1 2 4 4 5}$ & 55103 \\
\hline 7 & Drinking milk 3.2\% & 126216 & 407930 & 123439 \\
\hline 8 & $30 \%$ cream 0.5 litres & 8058 & 244401 & 5706 \\
\hline 9 & $30 \%$ cream & 200 & 6040 & 141 \\
\hline 10 & $18 \%$ cream 0.25 litres & 19862 & 361805 & 3458 \\
\hline 11 & $18 \%$ cream & 4465 & 34216 & 264418 \\
\hline 12 & Semi-skimmed cottage cheese & 33560 & 213240 & 2545 \\
\hline 13 & Milk sold at procurement & 2646 & 10122 & 5526869 \\
\hline & Total & & 19641006 & $112,445)$ \\
\hline
\end{tabular}

* e.g. for $2 \%$ bulk milk the fat unit consumption is the standard times the quantity $(55,943 \times \mathbf{2 . 0 1}=112,445)$ Source: authors' own elaboration.

In the calculation of dairy products, account shall be taken of the costs of preparing the production which relate to the product being manufactured for the first time or, where new technology is applied, to the product to which it relates. 
Table 4. Clearance of purchase and procurement costs

\begin{tabular}{|l|r|}
\hline \multicolumn{1}{|c|}{ Content } & Amount (PLN) \\
\hline 1. Total purchase and procurement costs, including: & 824982 \\
\hline a) purchase costs & 11868 \\
\hline b) procurement costs & 813197 \\
\hline $\begin{array}{l}\text { 2. Net value of raw material consumed } \\
\text { a) the value of purchased raw material }\end{array}$ & $406589 *$ \\
\hline 3. Value of raw material (basis for determining the rate of & 7927432 \\
procurement and purchase cost mark-up) (2-2a) & $813197: 7927432=0,102580129$ \\
\hline Ratio & \\
\hline
\end{tabular}

* Net raw material is the value of the raw material minus the waste: gross raw material $=4,404,165+3,938,961$

$=8,343,126$ minus the value of the waste - in our example $9,105=8,334,021$

* Value of raw material purchased (fat and plasma units) 9,394 + 397,195=406,589

Source: authors' own elaboration.

The costs of procurement and purchase of raw material are charged directly to the specified product, by means of detailed off-book accounting records (Table 4). Where it is not possible to allocate purchase and procurement costs directly to a product, coefficients established within the relevant cooperative shall be applied and accounted for on the basis of the net consumption of raw material per product or on the basis of the sum of the inputed units. Purchase and procurement costs are not accounted for on buttermilk and products made from it, and on own whey products, as they do not include inputed units. The costs of purchase and purchase in the investigated cooperative amounted to approximately PLN 825 thousand and for their settlement the value of total raw material minus the value of purchased raw material was taken as the basis. The clearing factor was 0.102580129 .

Departmental costs are accounted for on a per-product basis through cost-intensity ratios, determined by the management, multiplied by the volume of production. They are usually determined by the labour intensity of the product, its weight, etc. An important issue in determining the coefficients is the adoption of such a measure that will reflect the actual relationship between the cost and the cost carrier - the product, therefore it would be advisable to settle these costs in relation to the net consumption of raw material or the sum of the calculation units. Departmental costs are not accounted for in relation to milk that is already sold at the collection centre (Table 5). In the cooperative studied, departmental costs were accounted for with reference to the departmental cost mark-up ratio, calculated by dividing the value of departmental costs by the number of costing units. The cooperative has four departments: liquid products, cottage cheese, powder and butter plant. The highest departmental costs are incurred in the powder plant. The costs of losses due to production shortages are accounted directly to the product in the manufacture of which the shortage was identified. If, on the other hand, by-products are generated in the production of a given product, the production costs of the main product are reduced by the value of the by-products at their selling price ${ }^{4}$.

\footnotetext{
${ }^{4}$ By-products are valued at their realisable selling prices.
} 
Table 5. Clearance of departmental costs

\begin{tabular}{|c|r|r|r|}
\hline Departments & $\begin{array}{c}\text { Number of calculation } \\
\text { units - contractual* }\end{array}$ & $\begin{array}{c}\text { Departmental costs } \\
\text { (PLN) }\end{array}$ & $\begin{array}{c}\text { Cost mark-up ratio } \\
\text { (departmental costs : number of } \\
\text { basic units) }\end{array}$ \\
\hline Liquid articles & 729457 & 370819 & $0,50834936^{* *}$ \\
\hline Cottage cheese plant & 33560 & 84599 & 2,52082836 \\
\hline Milk powder plant & 457725 & 1022090 & 2,23297831 \\
\hline Butter plant & 184283 & 338706 & 1,83796660 \\
\hline Total & & 1816214 & \\
\hline
\end{tabular}

* The number of calculation units - contractual units is the quantity of output times a factor.

$* * 370,819: 729,457=0.05834936,84,599: 33,560=2.52082836,1,022,090: 457,725=2.23297831$

$338706: 184,283=1.83796660$

Source: authors' own elaboration.

Table 6. Unit production cost of dairy products

\begin{tabular}{|c|c|c|c|c|c|c|c|}
\hline Content & $\begin{array}{l}\text { Consumption } \\
\text { according to } \\
\text { standards per unit }\end{array}$ & $\begin{array}{c}\text { Cost } \\
\text { (PLN/unit) }\end{array}$ & $\begin{array}{c}\text { Cost of raw } \\
\text { material } \\
(\mathrm{PLN} / \mathrm{l}, \mathrm{kg})\end{array}$ & $\begin{array}{c}\text { Costs of } \\
\text { direct } \\
\text { materials } \\
(\mathrm{PLN} / 1, \mathrm{~kg})\end{array}$ & $\begin{array}{c}\text { Purchase and } \\
\text { procurement } \\
\text { costs } \\
(\mathrm{PLN} / \mathrm{l}, \mathrm{kg})\end{array}$ & $\begin{array}{l}\text { Departmental } \\
\quad \text { costs } \\
(\mathrm{PLN} / 1, \mathrm{~kg})\end{array}$ & $\begin{array}{c}\text { Unit } \\
\text { Manufacture } \\
\text { Cost } \\
\text { (PLN/ } 1, \mathrm{~kg})\end{array}$ \\
\hline
\end{tabular}

\begin{tabular}{|c|c|c|c|c|c|c|c|c|c|}
\hline & Fat & Plasma & Fat & Plasma & & & & & \\
\hline Milk powder (kg) & 8,1 & 10,93 & 0,2 & 0,69 & 9,40 & 0,11 & 0,96 & 2,05 & 12,52 \\
\hline $\begin{array}{l}\text { Packaged butter } \\
(\mathrm{kg})\end{array}$ & 75,7 & 0,35 & 0,2 & 0,69 & 17,22 & 0,43 & 1,77 & 1,69 & 21,11 \\
\hline Extra butter $(\mathrm{kg})$ & 83,9 & 0,30 & 0,2 & 0,69 & 19,04 & 0,47 & 1,95 & 1,69 & 23,15 \\
\hline Buttermilk feed (l) & 0,40 & 1,00 & 0,2 & 0,69 & 0,78 & 0,01 & 0,08 & 0,47 & 1,34 \\
\hline Drinking milk $2 \%$ & 2,02 & 0,99 & 0,2 & 0,69 & 1,14 & 0,02 & 0,12 & 0,47 & 1,74 \\
\hline $\begin{array}{l}\text { Drinking milk } 2 \% \\
\text { (l) }\end{array}$ & 2,01 & 0,98 & 0,2 & 0,69 & 1,13 & 0,02 & 0,12 & 0,47 & 1,73 \\
\hline $\begin{array}{c}\text { Drinking milk } \\
3.2 \%(\mathrm{l})\end{array}$ & 3,23 & 0,98 & 0,2 & 0,69 & 1,40 & 0,02 & 0,14 & 0,47 & 2,04 \\
\hline $\begin{array}{l}30 \% \text { cream } 0.5 \\
\text { litres (l) }\end{array}$ & 30,3 & 0,71 & 0,2 & 0,69 & 7,29 & 0,17 & 0,75 & 0,47 & 8,68 \\
\hline $30 \%$ cream (l) & 30,2 & 0,71 & 0,2 & 0,69 & 7,26 & 0,17 & 0,75 & 0,47 & 8,65 \\
\hline $\begin{array}{c}18 \% \text { cream } 0.25 \\
\text { litres (l) }\end{array}$ & 18,2 & 0,83 & 0,2 & 0,69 & 4,66 & 0,11 & 0,48 & 0,47 & 5,71 \\
\hline $18 \%$ cream (l) & 7,6 & 0,77 & 0,2 & 0,69 & 2,26 & 0,05 & 0,23 & 0,47 & 3,00 \\
\hline cottage cheese $(\mathrm{kg})$ & 6,3 & 7,88 & 0,2 & 0,69 & 6,89 & 0,08 & 0,71 & 2,31 & 9,99 \\
\hline $\begin{array}{l}\text { Milk sold at } \\
\text { procurement (l) }\end{array}$ & 3,8 & 0,96 & 0,22 & 0,69 & 1,53 & 0,03 & 0,16 & 0,47 & 2,18 \\
\hline
\end{tabular}

Source: authors' own elaboration.

Once the cost of production has been determined, the own cost of dairy products sold is determined, accounting for management costs and selling costs. Management costs, known as overhead, are charged to products, usually taking as a basis the sum of purchase and procurement costs and departmental costs (this may be a different basis depending on 
the basis established by the cooperative), which are then charged to products using an added coefficient (overheads divided by the basis for charging these costs). The basis for calculating the costs of sales for specific products is off-book records (Bazydło, Sokołowski 1998). Selling costs consist of direct costs attributable to the product in question and common costs, which in the cooperative studied are calculated as follows:

- the cost of distributing certain dairy products to the retail network in relation to the volume of products sold in a given period,

- other selling costs in relation to all products sold in a given period.

Based on the cost information obtained, the unit production cost of dairy products is determined (Table 6).

The highest manufacturing cost per unit was for extra butter and pre-packed table butter. In dairy cooperatives, butter is the most cost-intensive product when using the methodology of accounting for indirect costs on dairy products.

\section{Conclusions}

There have been no significant and radical changes in management, including the functioning of cost accounting, in cooperative dairying in Poland. The main cost accounting transformations were minor modifications concerning the choice of basis for allocating indirect costs to products, which in a changing market environment is a negative situation. Dairy cooperatives in Poland need new solutions for cost accounting in order to face competition from other legal forms operating in the milk market. The majority of Polish dairy cooperatives in the food industry do not systematically use solutions within modern cost accounting systems. The implementation of such a system often requires not only the reconstruction of cost accounting and changes in reporting and analysis principles, but also the reconstruction of management structures. Therefore, only selected problem accounts are generally maintained when the need arises

The methodology adopted by the cooperative for cost accounting is based on the division of costs into direct and indirect costs, which significantly limits the possibilities for management decisions. Moreover, the method of calculating the unit cost of dairy products, based mainly on the inputs of the raw material, distorts the level of the cost of production and significantly inflates it, e.g. in the case of butter.

The main problem that should be highlighted is the lack of an adequate cost accounting information system. The implementation of such solutions would allow the managers of a dairy cooperative to make appropriate (short-term) decisions on the development of the assortment structure based on data such as profitability at the level of individual products.

The solutions used in the cooperative surveyed for allocating indirect costs to products in relation to the number of calculation units (fat and plasma) distort the cost information in the case of, for example, butter, the production of which is raw materialintensive (thus consisting of more calculation units), resulting in a higher amount of indirect costs being allocated to this product. Therefore, it can be assumed that the information system of the applied full cost accounting in a dairy cooperative is not completely reliable, especially for short-term decisions (e.g. regarding profitability at the level of individual products). It would therefore make sense to introduce variable costing, 
which would improve the decision-making process regarding manufactured products, mainly in terms of their assortment structure and production optimisation.

Moving towards the use of variable costing in dairy cooperatives can provide cooperative managers with information about profitability at the level of the individual product. On this basis, they could make decisions regarding the choice of the product mix structure of the manufactured products. In order to imply variable costing, it would be necessary to introduce a controlling procedure, which would considerably improve the cost management area. It is important that the identification of ways to improve the efficiency of dairy cooperatives within the framework of using information from the cost accounting system covers all areas of their operation.

\section{References}

Alnestig P., Segerstedt A., Product costing in ten Swedish manufacturing companies, Economics, 46-47, 1996, p. 441-458.

Bazydło I., Sokołowski T., Rozliczanie surowca w zakładach mleczarskich. Krajowe Porozumienie Spółdzielni Mleczarskich, Związek Rewizyjny, Warszawa 1998, s. 5.

Black T., Gray Ph., The effect of the production volume variance on absorption costing income, Accounting and Finance, 35, 1, 133-143, 1995.

Borkowski B., Dudek H., Szczesny W., Ekonometria. Wybrane zagadnienia. Wydawnictwo Naukowe PWN, Warszawa 2003, s. 98.

Bruegelmann T., How variable costing is used in pricing decisions, in Management Accounting, 66, no. April, 1985, p. 58-63

Chmielewska M., Kalkulacja kosztów spółdzielni mleczarskiej z wykorzystaniem różnych podstaw podziału kosztów pośrednich. Zarządzanie produkcją i logistyką - koncepcje, metody i rozwiązania praktyczne. Wydawnictwo Instytutu Inżynierii Zarządzania Politechniki Poznańskiej, Poznań 2006. Czubakowska K., Gabrusiewicz W., Nowak E., Fundamentals of managerial accounting, Polish Economic Publishing House, p. 16, Warsaw 2006.

Dickhaut J., Lere J., Comparison of Accounting Systems and Heuristics, Selecting Economic Optima, in Journal of Accounting Research, 21, 2, 495-514, 1983.

Doost R., Allocating the cost of accounting for com- puter services, The CPA Journal, 66, 6, 68-69. Ganc M., Soliwoda M., Usefullnes of Variable Costs Accounting in Dairy Cooperatives in Poland, Management and Production Engineering Review, vol. 2, 2011, 16-21.

Ganc, M., The usefulness of costs worksheet to manage costs in dairy cooperatives Zarządzanie Finansami i Rachunkowość, 2017, vol.5, nr 3, s. 35-44.

Garrison R.H., Noreen E.W., Managerial Accounting, Burr Ridge, IL, Irwin, 1994.

Horngren C.T., Foster G., Datar S.M., Cost Ac- counting, A Managerial Emphasis, 9th ed., NJ: Prentice-Hall, Englewood Cliffs, 1997, p. 263.

Jaruga A., Nowak W., Szychta A., Managerial Accounting- concepts and applications, Publisher Graduate, Lodz 1999, p. 35.

Nowak E. [Ed.], Kacprzak K., Statistical methods in the analysis of the company's activities, Polish Economic Publishing House, Warsaw 2001, p. 189.

Reinstein A., Bayou M.E., Product costing continuum for managerial decision, Managerial Auditing Journal, 12, 9, 490-497, 1997.

Rogowska E. 2013: Systematyczny rachunek kosztów jako narzędzie wspomagające pozyskiwanie informacji do celów zarządzania przedsiębiorstwem, Zeszyty Naukowe Uniwersytetu Szczecińskiego nr 765, Finanse, Rynki Finansowe, Ubezpieczenia, nr 61, t. 2, s. 225-341.

Schiff M., Variable costing: a closer look, Manage ment Accounting, 68, No. February, 36-40, 1987. Stanisławski K. [Ed.], Dairy industry in Poland, Wydawnictwo Czarno-Biała, Bydgoszcz 2006, p. 2. 
Tishlias D.P., Chalos P., Product Pricing Behavior Under Different Costing Systems, Accounting and Business Research, 18, 71, 257-266, 1988.

Turner M., Hilton R., Use of Accounting Product- Costing Systems in Making Production Decisions, Journal of Accounting Research, 27, 2, 297-313, 1989.

Wasilewski M., Kowalczyk A., A comparative analysis of dairy cooperatives according to quality of management and production, Electronic Journal of Polish Agricultural Universities, Economics, 7, 2, 1-10, 2004.

Wasilewski M., Chmielewska M., Practical aspects budgeting the costs of dairy cooperatives, Scientific Papers of Wroclaw AE, No. 1121, p. 235, Wroclaw 2006.

Włodarczyk H., Górniak J., Costs acounting In dairy cooperatives, Sannpollac Sp. z o.o. Warsaw 1992, p. 8.

\section{Metodyka rozliczania i kalkulacji kosztów w spółdzielni mleczarskiej}

\section{Streszczenie}

Celem badań jest przedstawienie teoretycznych oraz praktycznych aspektów ustalania jednostkowego kosztu wytworzenia produktów mleczarskich w jednej określonej jako „typowa” spółdzielni mleczarskiej. Dla określenia obiektu typowego $\mathrm{z} \mathrm{n}=88$ spółdzielni mleczarskich wykorzystano metodę odległości euklidesowej i miejskiej - określono zestaw zmiennych, które są wspólne dla wszystkich spółdzielni i odzwierciedlają wielkość oraz specyfikę spółdzielczych jednostek na rynku mleka w Polsce. W wybranej spółdzielni przedstawiono procedurę kalkulacji kosztów jednostkowych produktów mleczarskich na podstawie szczegółowego case study. Stosowany w spółdzielniach rachunek kosztów pełnych nie zapewnia pozyskiwania informacji o kosztach do podejmowania decyzji zarządczych. Rozliczanie kosztów pośrednich przy wykorzystaniu umownych współczynników nie zapewnia wiarygodnych danych o kosztach. Istotną kwestią przy ustalaniu współczynników jest przyjęcie takiej miary, która odzwierciedli rzeczywisty związek między kosztem a nośnikiem kosztu - wyrobem, co w przypadku wyrobów mleczarskich może być utrudnione. Zasadne byłoby podjęcie próby wprowadzenia rachunku kosztów zmiennych w spółdzielniach mleczarskich, co umożliwiłoby uniknięcie umownego przypisania kosztów pośrednich na wyroby. Głównym problemem, na który zwracają uwagę Autorzy, jest brak odpowiedniego systemu informacyjnego rachunku kosztów w spółdzielniach mleczarskich. Wdrożenie takich rozwiązań pozwoliłoby zarządzającym spółdzielnią mleczarską na podejmowanie odpowiednich decyzji (krótkookresowych) w zakresie opracowania struktury asortymentu w oparciu o dane np. o zyskowności na poziomie pojedynczych produktów.

Słowa kluczowe: spółdzielnie mleczarskie, kalkulacja kosztów, rachunek kosztów.

Kody JEL: M49, Q19, P13.

Information about the authors:

Dr hab. Mirosław Wasilewski, prof. SGGW w Warszawie, Instytut Ekonomii i Finansów,

Katedra Finansów,

Nowopursynowska Street 166, 02-776 Warsaw, e-mail: miroslaw_wasilewski@sggw.edu.pl

ORCID: 0000-0001-6791-5713 
Dr Marzena Ganc,

Instytut Ekonomii i Finansów,

Katedra Finansów,

Nowopursynowska Street 166, 02-776 Warsaw,

e-mail: marzena_ganc@sggw.edu.pl

ORCID: 0000-0002-5267-7940 